\title{
A STUDY ON IMPACT OF ELECTRONIC POINT OF SALE (E-POS) SYSTEM AMONG PUBLIC DISTRIBUTION SYSTEM (PDS) BENEFICIARIES
}

\author{
${ }^{1}$ Anjana P R and ${ }^{2}$ PraveenaVijayan \\ ${ }^{1}$ Anjana P R, MCom Final year student, Department of Commerce, Sree Narayana \\ CollegeNattika,(Affiliated to University of Calicut), P.O.Nattika, Thrissur, Kerala 680566. \\ ${ }^{2}$ Smt. PraveenaVijayan, Assistant Professor, Department of Commerce, Sree Narayana College \\ Nattika,(Affiliated to University of Calicut), P.O.Nattika, Thrissur, Kerala 680566.
}

DOI: 10.46609/IJSSER.2020.v05i09.008 URL: https://doi.org/10.46609/IJSSER.2020.v05i09.008

\begin{abstract}
The public distribution system (PDS) evolved as a system of management of scarcity through distribution of food grains at affordable prices. It has a great role in our country for eradicating poverty. It was established by Government of India under Ministry of Consumer's affairs, food and public distribution to distribute food and non-food items to public at subsidized rates. Online Authentication Services provided by UIDAI (fingerprints, iris and photo for face recognition) are used for the sale of PDS commodities to BPL beneficiaries in all Fair Price Shops (FPS). This has improved efficiency and transparency in the system and enabled on time ration delivery to eligible beneficiaries. In order to make the Rationing system high tech the government implemented E-POS machine in Ration Shops in Kerala. With this, the public distribution mechanism in the state will move into the Aadhaar-enabled PDS (AePDS) mode. In this study an attempt is made to examine the impact of Electronic Point of Sale (E-Pos) System among Public Distribution System (PDS) Beneficiaries with special reference to Pavaratty Panchayat, Thrissur district. There is a need for increase in the quantity of food items given through ration shop and also need to ensure the quality of food grains supplied to consumers.
\end{abstract}

Keywords: Public Distribution System(PDS), E-POS, AePDS

\section{INTRODUCTION}

Public Distribution System (PDS) is a food security system established by the Government of India under Ministry of consumer affairs, food and public distribution and managed jointly with state governments in India. It distributes subsidized food and non-food items to all sectors of the 
International Journal of Social Science and Economic Research

ISSN: 2455-8834

Volume:05, Issue:09 "September 2020"

society. To certain extend PDS helps to bridge the gap between have and have not. As seen in every system corruption and malpractices have crept into the system knowingly or unknowingly. In order to have transparency in the PDS system and to avoid the malpractices Government introduced digitalization in PDS. The main aim of Public Distribution System is to deliver goods to ultimate beneficiaries at the right time, right place, right quality, quantity and at right price. This is possible only with the effective support of both Government and staff members of PDS.

As a solution to various issues, the government has introduced EPOS (electronic point of sale) system and has invoked both criticism as well as appreciations from different strata of society. So this study attempts to draw light on the impact of EPOS machines from the view point of beneficiaries and to analyze the level of satisfaction of beneficiaries regarding the performance of ration shops and to highlight the major problems associated with the performance of PDS. Also an attempt is made to find out the major changes happened in this sector after digitalization.

The food and civil supplies department of Kerala government has been battling various issues like corruption, misuse of rations allotted to the fair price shops by the vendors, misappropriation of commodities by shadows who use fake ration cards. As a solution to track the issues of flow of ration in the FPS to the beneficiary, the government has introduced electronic point of sale (EPOS) machines from January 7, 2018. Therefore, in this study an attempt is made to assess the impact of Electronic Point of Sale (E-Pos) System among Public Distribution System (PDS) beneficiaries

\section{REVIEW OF LITERATURE}

This session provide some of the major studies related with PDS system.

Athira G and Gopika GG (2019) conducted a study on the topic "Impact and issues of Aadhaar enabled public distribution system in Kerala"to analyze the effectiveness of this system. The results revealed that Aadhaar enabled public distribution system functioned more effectively than the old system and its increases the transparency. And they also listed some problems associated with this system like poor internet connectivity and other technical errors.

$>$ Neethu AbeyGerorge and Fiona H Mcky (2019) conducted a study on the topic "The public distribution system and food security in India". Under this they studied about the public distribution system at a glance its features, functions, goals, benefits and challenges. And they listed out the existing corruptions and limitations and also suggest the measures to overcome the barriers are discussed in this study.

$>$ SwapnaShaji and Annie John (2018) they conducted a study on the topic "The impact of E-pos machines in ration shops. Under this study they examined the satisfaction level 
International Journal of Social Science and Economic Research

ISSN: 2455-8834

Volume:05, Issue:09 "September 2020"

of the beneficiaries after digitalization. The results reveal that there are no significant differences in the level of satisfaction after the implementation of the E-POS system.

$>$ Dipthi Paridhi Kindo (2017) conducted a study on the topic "Aadhaar enabled public distribution system a case study". In this study they describe the steps involved in the digitalization process and the benefits of digitalization and also state major challenges involved in digitalization.

D. Mahalingam and Akash Raj D P (2017) conducted a study on the topic "Major draw backs of public distribution system in India". The main aim of this article is to illustrate the major drawbacks of PDS in India through various studies conducted in this country. The performance and problems of PDS varies regionally based on the implementation of the system by state governments and union territories hence this article would give a holistic picture of major problems in public distribution system in country.

$>$ RashmiPanshare and MayurRewatkar (2016) conducted a study on the topic "Modern public distribution system for digital India". Under this they describe the techniques or methods used to reduce the level of corruption.

C. Angrup Bodh (2016) in the study "Evaluation study on role of PDS in shaping house hold and nutritional security in India" revealed the PDS has a great role in the welfare of every family and every family considered PDS as a determinant of family welfare. And suggests that this sector should give more care to the nutritional security.

\section{OBJECTIVES OF THE STUDY}

- To examine the satisfaction level of the beneficiaries regarding the ration shops after the implementation of E-POS system

- To find out the major problems associated with the implementation of E-POS system.

- To examine the major changes happened in PDS after digitalization

\section{RESEARCH METHODOLOGY}

The study was conducted by means of personal interview with respondents and the information given by the respondents were directly recorded on questionnaire.

\subsection{SOURCES OF DATA}

$>$ Primary data

The primary data are those which are collected raw for the first time. This was collected with the help of structured questionnaire from the ration beneficiaries residing in Pavaratty panchayath of Thrissur district 
Secondary data

The secondary data are those which had already collected by someone else and which have passed through the statistical process. In this study the secondary data was collected from various sources like existing reports, books, journals, and websites

\subsection{SAMPLE SIZE}

The sample size is 50 and they were selected from the ration beneficiaries residing in Pavaratty panchayath of Thrissur district using convenience sampling method.

\subsection{STATISTICAL TOOLS}

The study uses simple mathematical and statistical tools like percentage analysis, arithmetic mean, standard deviation and ranking method for data analysis.

\section{DATA ANALYSIS AND INTERPRETATION}

\subsection{Gender wise classification of data}

\begin{tabular}{|l|c|c|}
\hline \multicolumn{1}{|c|}{ Gender } & Number of respondents & Percentage \\
\hline Male & 16 & 32 \\
\hline Female & 34 & 68 \\
\hline Total & $\mathbf{5 0}$ & $\mathbf{1 0 0}$ \\
\hline
\end{tabular}

Interpretation:

Out of 50 respondents, $68 \%$ of respondents are females and the rest $32 \%$ are males. Thus it is inferred that majority of respondents are females.

\subsection{Age wise distribution of data}

\begin{tabular}{|l|c|c|}
\hline \multicolumn{1}{|c|}{ Age } & Number of respondents & Percentage \\
\hline Up to 20 & 4 & 8 \\
\hline $21-40$ & 15 & 30 \\
\hline $41-60$ & 23 & 46 \\
\hline Above 60 & 8 & 16 \\
\hline Total & $\mathbf{5 0}$ & $\mathbf{1 0 0}$ \\
\hline
\end{tabular}

Interpretation: 
Out of 50 samples $46 \%$ comes under the age group of 41-60. 30\% include under the age group of 21-40. 16\% include the age group of above 60 and $8 \%$ comes under up to 20 .

\subsection{Educational qualification of respondents}

\begin{tabular}{|l|c|c|}
\hline Educational Qualification & Number of respondents & Percentage \\
\hline Up to SSLC & 18 & 36 \\
\hline Plus two & 14 & 28 \\
\hline U G & 10 & 20 \\
\hline P G & 3 & 6 \\
\hline Others & 5 & $\mathbf{1 0 0}$ \\
\hline Total & $\mathbf{5 0}$ & 10 \\
\hline
\end{tabular}

Interpretation

The above table depicts that out of 50 respondents, $36 \%$ of respondents have educational qualification up to SSLC and 28\% respondents have completed HSE, 20\% respondents are degree holders, $6 \%$ of respondents are post graduates and $10 \%$ of respondents have other qualifications.

5.4 Occupation wise classification of respondents

\begin{tabular}{|l|c|c|}
\hline \multicolumn{1}{|c|}{ Occupation } & Number of respondents & Percentage \\
\hline Agriculture & 3 & 6 \\
\hline Government Sector & 5 & 10 \\
\hline Private sector & 17 & 34 \\
\hline Business & 4 & 8 \\
\hline Home maker & 14 & 14 \\
\hline Others & 7 & $\mathbf{1 0 0}$ \\
\hline Total & $\mathbf{5 0}$ & 28 \\
\hline
\end{tabular}

Interpretation

The table shows that, majority of respondents $34 \%$ are working in the private sector, $28 \%$ of respondents are homemakers and $14 \%$ of respondents are engaged in other sectors. Only $10 \%$ of 
International Journal of Social Science and Economic Research

ISSN: 2455-8834

Volume:05, Issue:09 "September 2020"

respondents are working in Government service and others are engaged in agriculture, and business field.

\subsection{Income wise distribution of data}

\begin{tabular}{|l|c|c|}
\hline \multicolumn{1}{|c|}{ Income } & Number of respondents & Percentage \\
\hline Up to 10000 & 16 & 32 \\
\hline $10001-30000$ & 21 & 42 \\
\hline $30001-50000$ & 8 & 16 \\
\hline Above 50000 & 5 & 10 \\
\hline Total & $\mathbf{5 0}$ & $\mathbf{1 0 0}$ \\
\hline
\end{tabular}

Interpretation

Above table depicts that out of 50 respondents, $32 \%$ of respondents are earning up to 10000 , $42 \%$ of respondents are belongs to the income group ranging from 10001-30000,16\% are belong to the income group of 30001-50000 and only 10\% of respondents are earning above 50000. Thus it is inferred that majority of respondents are earning income in the range of 10001-30000.

\subsection{Type of ration card}

\begin{tabular}{|l|c|c|}
\hline \multicolumn{1}{|c|}{ Category } & Number of respondents & Percentage \\
\hline Annapurna & 5 & 10 \\
\hline APL( blue) & 22 & 44 \\
\hline BPL(pink) & 17 & 34 \\
\hline AAY(yellow) & 6 & 12 \\
\hline Total & $\mathbf{5 0}$ & $\mathbf{1 0 0}$ \\
\hline
\end{tabular}

Interpretation

Above table shows that most of the respondents $44 \%$ are APL card holders. $34 \%$ of the respondents holds BPL ration cards. $12 \%$ of respondents hold AntyodayaAnnaYojana (AAY) card i.e. they are the most economically backward section of society. Only least respondents $10 \%$ holds white card and they are non-priority sector.

\subsection{Type of house hold}


International Journal of Social Science and Economic Research

ISSN: 2455-8834

Volume:05, Issue:09 "September 2020"

\begin{tabular}{|l|c|c|}
\hline \multicolumn{1}{|c|}{ Type } & Number of respondents & Percentage \\
\hline Nuclear & 32 & 64 \\
\hline Joint & 18 & 36 \\
\hline Total & $\mathbf{5 0}$ & $\mathbf{1 0 0}$ \\
\hline
\end{tabular}

Interpretation

Majority of the respondents $64 \%$ comes under nuclear family type. And 36\% comes under joint family.

5.8 Regular purchase of commodity from ration shops

\begin{tabular}{|l|c|c|}
\hline \multicolumn{1}{|c|}{ Opinion } & Number of respondents & Percentage \\
\hline Yes & 42 & 84 \\
\hline No & 8 & 16 \\
\hline Total & $\mathbf{5 0}$ & $\mathbf{1 0 0}$ \\
\hline
\end{tabular}

Interpretation

$84 \%$ of the respondents purchase commodities regularly from ration shops include and $16 \%$ are not.

\subsection{Linkage of Aadhar card with ration card}

\begin{tabular}{|l|c|c|}
\hline Opinion & Number ofrespondents & Percentage \\
\hline All members & 15 & 30 \\
\hline One member & 7 & 14 \\
\hline More than one member & 28 & 56 \\
\hline Total & $\mathbf{5 0}$ & $\mathbf{1 0 0}$ \\
\hline
\end{tabular}

Interpretation

In 56\% families' more than one member is linked with Aadhaar card. And in $30 \%$ families all members Aadhaar card are linked with ration cards.

\subsection{Awareness of working of E-POS}


International Journal of Social Science and Economic Research

ISSN: 2455-8834

Volume:05, Issue:09 "September 2020"

\begin{tabular}{|l|c|c|}
\hline \multicolumn{1}{|c|}{ Options } & Number & Percentage \\
\hline Know very well & 13 & 26 \\
\hline Know almost & 29 & 58 \\
\hline Know some what & 8 & 16 \\
\hline Total & $\mathbf{5 0}$ & $\mathbf{1 0 0}$ \\
\hline
\end{tabular}

Interpretation

The table reveals that $84 \%$ of the respondents are aware about the working of E-Pos system. And $6 \%$ are less aware about the working of E-POS system.

5.11 Satisfaction level of beneficiaries after the implementation of E-POS

\begin{tabular}{|l|l|l|l|l|}
\hline NO & \multicolumn{1}{|c|}{ Statements } & Mean & SD & \multicolumn{1}{|c|}{$\begin{array}{c}\text { Level of } \\
\text { satisfaction }\end{array}$} \\
\hline 1 & Transparency in dealings & 3.66 & 0.907 & Satisfied \\
\hline 2 & Availability of bill & 3.98 & 0.924 & Satisfied \\
\hline 3 & Time management & 2.18 & 0.864 & Dissatisfied \\
\hline 4 & $\begin{array}{l}\text { Proper information on availability of } \\
\text { goods }\end{array}$ & 4.02 & 0.990 & Highly satisfied \\
\hline 5 & Working of machines & 2.08 & 0.868 & Dissatisfied \\
\hline 6 & Behavior shop dealer & 3.44 & 0.962 & Neutral \\
\hline 7 & $\begin{array}{l}\text { Supplying the items as prescribed by the } \\
\text { government }\end{array}$ & 4.06 & 0.968 & Highly satisfied \\
\hline 8 & Prompt quantity & 2.58 & 1.079 & Dissatisfied \\
\hline 9 & Finger print scanning & 2.54 & 1.080 & Dissatisfied \\
\hline 10 & $\begin{array}{l}\text { Distribution of commodities to real } \\
\text { beneficiaries }\end{array}$ & 3.94 & 0.988 & Satisfied \\
\hline
\end{tabular}

Interpretation

Statement 1 


\section{International Journal of Social Science and Economic Research}

ISSN: $2455-8834$

Volume:05, Issue:09 "September 2020"

The respondents are satisfied in the dealings of ration shop after digitalization. They said that the activities have become more transparent after the implementation of the E-Pos system.

Statement 2

Respondents are satisfied with the statement that availability of bill for each purchase. After digitalization for every single purchase they get bill from the E-POS machine.

\section{Statements 3}

Time management is considered as a dissatisfying factor. Because some bio metric procedures each transactions consume more time.

\section{Statement 4}

Respondents are highly satisfied with the statement that after epos system there is proper information about the availability of goods. Information about the quantity, prices etc. are made available to the beneficiaries through SMS.

\section{Statement 5}

Respondents are not satisfied in the working of machines. There is too much inefficiency in the working of machines due to poor internet connectivity etc.

Statement 6

No clear view is received about the behavior of the ration shop dealer. It remains the same after the digitalization.

\section{Statement 7}

Respondents are highly satisfied with the statement that after implementing epos system, PDS is supplying the items as prescribed by the government, because it enables accurate recording of the quantity of grains sold to beneficiaries through the integrated weighting machine and uploading the transaction data to the central server

\section{Statement 8}

Beneficiaries dissatisfied in the quantity of the products received by them. There is no change in the quantity of products supplied from the ration shops after the implementation of biometric system.

Statement 9 
International Journal of Social Science and Economic Research

ISSN: 2455-8834

Volume:05, Issue:09 "September 2020"

Finger print recognition may fail some times and it is considered as another dissatisfying factor and its lag the time for each transaction.

Statement 10

Respondents are satisfiedwith the statement that the distribution of commodities is to the real beneficiaries after the implementation of epos system.

5.12 Ranking of problems faced by the beneficiaries after digitalization

\begin{tabular}{|l|l|l|l|l|l|l|l|l|l|l|}
\hline & R1 & R2 & R3 & R4 & R5 & R6 & R7 & R8 & Total & Rank \\
\cline { 1 - 6 } Weightage & 8 & 7 & 6 & 5 & 4 & 3 & 2 & 1 & & \\
\cline { 1 - 5 } $\begin{array}{l}\text { Lactors of operating } \\
\text { knowledge of the } \\
\text { dealer }\end{array}$ & 24 & 56 & 84 & 55 & 20 & 27 & - & - & 266 & 5 \\
\hline $\begin{array}{l}\text { Lack of public } \\
\text { awareness } \\
\text { programmes }\end{array}$ & - & 70 & - & 65 & 32 & 48 & 6 & - & 221 & 6 \\
\hline $\begin{array}{l}\text { Delay due to poor } \\
\text { internet } \\
\text { connectivity }\end{array}$ & 40 & 63 & 78 & 40 & 60 & - & - & - & 281 & 3 \\
\hline $\begin{array}{l}\text { Difficulties } \\
\text { finger } \\
\text { recognition }\end{array}$ & 4 & 49 & 60 & 45 & - & 12 & - & 2 & 312 & 1 \\
\hline $\begin{array}{l}\text { No provision for } \\
\text { representative } \\
\text { trading }\end{array}$ & - & - & 24 & 55 & 36 & 51 & 16 & 1 & 183 & 7 \\
\hline $\begin{array}{l}\text { System failure due } \\
\text { to poor quality of } \\
\text { machines }\end{array}$ & 8 & 35 & 66 & 70 & - & - & 8 & - & 307 & 2 \\
\hline
\end{tabular}


International Journal of Social Science and Economic Research

ISSN: 2455-8834

Volume:05, Issue:09 "September 2020"

\begin{tabular}{|l|l|l|l|l|l|l|l|l|l|l|}
\hline $\begin{array}{l}\text { Has to wait more } \\
\text { time in the queue }\end{array}$ & 80 & 35 & 72 & 40 & 44 & - & - & 4 & 275 & 4 \\
\hline $\begin{array}{l}\text { Linkage of } \\
\text { Aadhaar card with } \\
\text { ration card }\end{array}$ & - & - & 30 & 40 & 64 & - & 42 & - & 176 & 8 \\
\hline
\end{tabular}

Interpretation

This table shows ranking of problems faced by the beneficiaries after the implementation of EPos system. These factors are ranked from 1to 8 and the highest rank is for difficulties in finger print recognition and $8^{\text {th }}$ rank for linkage of Aadhaar card with ration card. And system failure due to poor quality is considered as the second major problem faced by the beneficiaries after the implementation of E-POS system. Delay in dealings is considered as the next problem. They have to spend more time to wait in queues, Lack of operating knowledge of the dealer, Lack of public awareness programmes, No provision for representative trading are ranked fourth fifth sixth and seventh respectively.

5.13 Ranking of major changes after digitalization

\begin{tabular}{|c|c|c|c|c|c|c|c|c|c|c|}
\hline & R1 & R2 & R3 & R4 & R5 & R6 & R7 & R8 & Total & Rank \\
\hline Weightage & \multirow[t]{2}{*}{8} & \multirow[t]{2}{*}{7} & \multirow[t]{2}{*}{6} & \multirow[t]{2}{*}{5} & \multirow[t]{2}{*}{4} & \multirow[t]{2}{*}{3} & \multirow[t]{2}{*}{2} & \multirow[t]{2}{*}{1} & & \\
\hline Factors & & & & & & & & & & \\
\hline Improve the quality of products & - & 7 & 18 & 35 & 20 & 45 & 24 & 7 & 156 & 7 \\
\hline Less transaction time & 8 & 14 & 30 & 35 & 24 & 39 & 20 & 6 & 176 & 6 \\
\hline $\begin{array}{l}\text { Possibility to purchase from } \\
\text { different ration shops }\end{array}$ & 40 & 63 & 72 & 40 & 40 & 12 & 4 & - & 271 & 3 \\
\hline Reduce fraudulent activities & 16 & 35 & 54 & 55 & 24 & 24 & 12 & 3 & 223 & 4 \\
\hline $\begin{array}{l}\text { Balance stocks are properly } \\
\text { transferred }\end{array}$ & 64 & 70 & 90 & 45 & 20 & 9 & - & - & 298 & 1 \\
\hline $\begin{array}{l}\text { Changes in the quantity of products } \\
\text { received. }\end{array}$ & - & 21 & 30 & 35 & 44 & 27 & 20 & 5 & 182 & 5 \\
\hline
\end{tabular}


International Journal of Social Science and Economic Research

ISSN: 2455-8834

Volume:05, Issue:09 "September 2020"

\begin{tabular}{|l|l|l|l|l|l|l|l|l|l|l|}
\hline $\begin{array}{l}\text { Possibility for representative } \\
\text { purchase }\end{array}$ & - & - & 6 & 15 & 36 & 33 & 28 & 12 & 130 & 8 \\
\hline $\begin{array}{l}\text { Less paper works and manual entry } \\
\text { of data. }\end{array}$ & 64 & 84 & 42 & 50 & 28 & 18 & - & - & 286 & 2 \\
\hline
\end{tabular}

Interpretation

This table shows the major changes happened in PDS sector after the implementation of E-Pos system. These changes are ranked from 1 to 8 and the major change happened after digitalization is that there is transfer of balance stocks to the next month properly ( $1^{\text {st }}$ rank). Second major change happened in this sector that need only less paper works and manual entry of data. And there is no possibility for representative purchasing (8th rank). And there is no change in the quality of products received after the implementation of biometric system (7th rank). There is decrease in the rate of black marketing and other fraudulent activities (4th rank) and the system became more transparent. There is a possibility to purchase from different ration shops after digitalization. There is only slight or no changes in the quantity of products received by the beneficiaries. There is lack of proper time management each transaction take more time.

\section{FINDINGS}

$>$ Majority of the respondents are (68\%) are females. Only $32 \%$ of the respondents are males.

$>46 \%$ of respondents comes under the age group of 41-60 and least comes under the group of under 20

$>$ Most of the respondents (36\%) have only education up to SSLC. Only less percentage of respondents are highly qualified.

$>$ Majority of the respondents (34\%) are working in the private sector followed by other sectors and least works in agriculture sector $6 \%$.

$>$ The income wise classification of respondents reveals that majority (42\%) of them falls under the income group between 10001-30000. Only 10\% respondents have income above 50000 .

$>$ Most of the respondents (44\%) are APL card holders. Second majority of respondents holds BPL ration cards. 12\% of respondents hold Antyodaya Anna Yojana (AAY) card i.e. they are the most economically backward section of society. Only least respondents $(10 \%)$ holds white card and they are non-priority sector.

$>64 \%$ of beneficiaries come under nuclear family. And 36\% comes under joint family.

$>$ Most of the beneficiaries regularly purchase products from ration shops.84\% 
$>$ In $56 \%$ families' more than one member is linked with Aadhaar card. And in $30 \%$ families all members Aadhaar card are linked with ration cards.

$>$ In majority families (86\%) the card owner themselves purchase the products. And in 14\% of families other members of the family used to purchase the products.

> $42 \%$ families highly depend on PDS for their livelihood.

$>84 \%$ of the respondents are fully aware about the information on working of E-POS system. And minorities of $16 \%$ are less aware about the working of E-POS system.

$>$ Majority of respondents (64\%) are not even making any complaints against the wrong function of ration shops.

$>$ The major reasons for not making complaints against the wrong functioning of ration shops are tedious procedure for filing the complaints, and lack knowledge about proper authority to which the complaints are to be filed.

$>$ Respondents are highly satisfied with the fact that proper Information about the availability of goods like the quantity, prices etc. are made available on a timely basis through SMS.

$>$ Respondents are also satisfied with the distribution of commodities after the implementation of E-POS system. Through the linkage of Aadhaar and biometric details E-POS system help to reduce the diversion of food grains.

$>$ Respondents are not satisfied in the quantity of the products and working of machines. There is too much inefficiency in the working of machines due to poor internet connectivity.

$>$ Time management is considered as a dissatisfying factor. Due to biometric procedure each transaction consume more time.

$>$ Failure of finger print recognition, poor quality of machines and lack of internet connectivity are considered as the major problem after the implementation of the E-POS system.

$>$ The major changes happened in the PDS sector after the implementation of biometric systems are.

1 There is transfer of balance stocks to the next month properly.

2 Need only less paper works and manual entry of data.

3 There is possibility to purchase from different ration shops.

4 Helps to reduce fraudulent activities

\section{SUGGESTIONS}




\section{International Journal of Social Science and Economic Research}

ISSN: $2455-8834$

Volume:05, Issue:09 "September 2020"

It is better to reduce the malpractices in PDS by conducting proper auditing, supervision and placing proper complaint boxes.

$>$ There are some reasons for not making complaints against the unsatisfactory matters happened in PDS shops, such as illiteracy, lack of interest, tedious procedures, lack of knowledge on proper authority to file complaint etc. Grievances can be reduced to an extend by creating awareness among the beneficiaries

$>$ Better connectivity facility need to be implemented for the efficient functioning of E-POS system.

\section{CONCLUSION}

This study shows that how effectively the ration shops are working in Pavaratty panchayath, Thrissur. The effectiveness has been accessed through the data collected from the municipal area. To conclude that most of people are depending on ration shops at least for an item. But in present situation the availability of food items is not adequate for the consumers. There is a need for increase in the quantity of food items given through ration shop and also need to ensure the quality of food grains supplied to consumers. The strong intervention from the government to ensure adequate supply to every poor in the society helps to eradicate poverty by attaining food security.

\section{REFERENCE}

Athira G and Gopika GG (2019) "Impact and issues of Aadhaar enabled public distribution system in Kerala", CESS seminar paper.

$>$ Neethu AbeyGerorge and Fiona H Micky (2019) conducted a study on the topic "The public distribution system and food security in India".Economic and Political Weekly, Vol. 35 (45).

$>$ SwapnaShaji and Annie John (2018) "The impact of E-pos machines in ration shops. Online research review journal. ICCMCT, special issue, ISSN : 2455-3085

$>$ Dipthi Paridhi Kindo (2017) "Aadhaar enabled public distribution system a case study". www.research gate/publications /328202233

> B. Mahalingam and Akash Raj D P (2017) "Major draw backs of public distribution system in India". International Journal for scientific research and development, vol.4, issue 09/2016, ISSN 2321-0613

$>$ RashmiPanshare and MayurRewatkar (2016) "Modern public distribution system for digital India". Seminar paper

$>$ C. Angrup Bodh (2016) "Evaluation studies on role of PDS in shaping house hold and nutritional security in India". Online research review journal. ICCMCT, special issue

$>$ www://epos.kerala.gov.in 
International Journal of Social Science and Economic Research

ISSN: 2455-8834

Volume:05, Issue:09 "September 2020"

$>$ https://civilsupplieskerala.gov.in

$>$ http://ecitizen.civilsupplieskerala.gov.in 